Hali, A., \& Telan, A. (2018). Pengaruh Beberapa Kombinasi Media Tanam Organik Arang Sekam, Pupuk Kandang Kotoran Sapi, Arang Serbuk Sabut Kelapa Dan Tanah Terhadap Pertumbuhan Dan Hasil

Tanaman Terung (Solanum Melongena L.). JURNAL INFO KESEHATAN, 16(1), 83-95. https://doi.org/10.31965/infokes.Vol16.Iss1.174

Jurnal Info Kesehatan

Vol 16, No.1, Juni 2018, pp. 83-95

P-ISSN 0216-504X, E-ISSN 2620-536X

Journal DOI: https://doi.org/10.31965/infokes

Website: http://jurnal.poltekeskupang.ac.id/index.php/infokes

R E S E A R C H

Open Access

\title{
Pengaruh Beberapa Kombinasi Media Tanam Organik Arang Sekam, Pupuk Kandang Kotoran Sapi, Arang Serbuk Sabut Kelapa Dan Tanah Terhadap Pertumbuhan Dan Hasil Tanaman Terung (Solanum Melongena L.)
}

\author{
Antonus Suban Hali \\ antoniushali@gmail.com
}

Pendidikan Fisika S1, Universitas Nusa

Cendana

\author{
Albina Bare Telan \\ albinatelan@poltekkeskupang.ac.id
}

Jurusan Kesehatan Lingkungan, Poltekkes
Kemenkes Kupang

\begin{abstract}
Abstrak
Tujuan dari penelitian ini adalah untuk mengetahui pengaruh perlakuan kombinasi beberapa media tanam organik seperti arang sekam, pupuk kandang kotoran sapi, arang sabut kelapadan tanah terhadap pertumbuhan dan hasil tanaman terung serta untuk mengetahui perlakuan kombinasi antar media tanam manakah yang dapat memberikan hasil tanaman terung terbaik. Penelitian ini dirancang dengan rancangan lingkungan berupa Rancangan Acak Lengkap (RAL) yang terdiri dari 8 perlakuan dan 3 ulangan. Variabel yang diamati meliputi pertambahan tinggi tanaman, pertambahan jumlah daun dan bobot buah. Data hasil pengamatan dianalisis dengan menggunakan analisis sidik ragam dan uji lanjut Duncan pada taraf 5\%. Hasil analisis menunjukan bahwa perlakuan kombinasi media tanam organikmampu memberikan pengaruh yang sangat nyata terhadap pertambahan tinggi tanaman terung pada 4 MST, 6 MST, 8 MST dan 10 MST, dan jumlah daun serta berpengaruh nyata terhadap jumlah buah. Perlakuan kombinasi media tanam organik yang memberikan capaian pertumbuhan dan hasil tanaman terung terbaik adalah pada perlakuan P8 dengan perlakuan kombinasi tanah:arang sekam padi:pupuk kandang sapi:arang sabut kelapa dengan perbandingan 1:1:1:1; pada perlakuan P7 dengan perlakuan kombinasi tanah:pupuk kandang sapi:arang sabut kelapa 1:1:1; dan perlakuan P3 dengan kombinasi perlakuan antara tanah:pupuk kandang sapi 1:1.
\end{abstract}

Kata kunci: Media Tanam Organik, Tanaman Terung, Kombinasi 


\title{
The Effect of Multiple Combinations of Organic Planting Media on Husk Charcoal, Fertilizer of Cow Manure, Coconut and Soil Powder Charcoal on the Growth and Yield of Eggplant (Solanum Melongena L.)
}

\begin{abstract}
The purpose of this study was to determine the effect of the combination treatment of several organic growing media such as husk charcoal, manure of cow manure, coarse coir charcoal on the growth and yield of eggplant plants and to find out which combination treatments between planting media can produce the best eggplant. This study was designed with an environmental design in the form of a completely randomized design (CRD) consisting of 8 treatments and 3 replications. The variables observed included plant height, number of leaves and fruit weight. Observation data were analyzed using analysis of variance and Duncan's follow-up test at 5\% level. The results of the analysis showed that the combination treatment of organizing media gave a very significant effect on the height increase of eggplant plants at 4 MST, 6 MST, 8 MST and 10 MST, and the number of leaves and a significant effect on the number of fruit. The treatment of the combination of organic planting media that gave the best growth and yields of eggplant was in the P8 treatment with a combination of soil treatment: rice husk charcoal: cow manure: coconut fiber charcoal with a ratio of $1: 1: 1: 1$; in P7 treatment with combination soil treatment: cow manure: 1:1:1 coconut husk charcoal; and P3 treatment with a combination of treatments between soil: $1: 1$ cow manure.
\end{abstract}

Keywords: Organic Planting Media, Eggplant Plants,Combination

* Correspondence: antoniushali@gmail.com

Present Address: Program Studi S1 Fisika, Universitas

Nusa Cendana, Kupang City, Indonesia

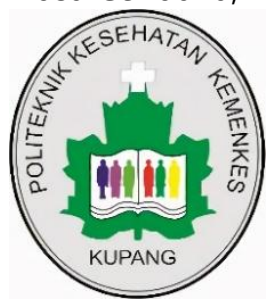

CThe Author(s) 2018. This article is distributed under the terms of the Creative Commons Attribution $\quad 4.0 \quad$ International License

(http://creativecommons.org/licenses/by/4.0/), which permits unrestricted use, distribution, and reproduction in any medium, provided you give appropriate credit to the original author(s) and the source, provide a link to the Creative Commons license, and indicate if changes were made. The Creative Commons Public Domain Dedication waiver (http://creativecommons.org/publicdomain/zero/1.0/) applies to the data made available in this article, unless otherwise stated. 
Hali, A., \& Telan, A. (2018). Pengaruh Beberapa Kombinasi Media Tanam Organik Arang Sekam, Pupuk Kandang Kotoran Sapi, Arang Serbuk Sabut Kelapa Dan Tanah Terhadap Pertumbuhan Dan Hasil

Tanaman Terung (Solanum Melongena L.). JURNAL INFO KESEHATAN, 16(1), 83-95. https://doi.org/10.31965/infokes.Vol16.Iss1.174

\section{PENDAHULUAN}

Terung (Solanum melongena L.) adalah jenis sayuran yang sangat populer dan disukai oleh banyak orang karena selain rasanya yang enak dan harganya relatif murah, kandungan gizi cukup tinggi yaitu protein, lemak, karbohidrat, vitamin, kalsium, fosfor dan zat besi (Soetasad dan Muryanti, 1996 dalam Leba, 2004). Komoditas ini sangat potensial untuk dikembangkan secara intensif dalam skala agribisnis. Pembudidayaan terung umumnya masih bersifat sampingan dipekarangan, ataupun lahan sawah dimusim kemarau, sehingga tidak heran bila hasil rata-rata terung di Indonesia masih rendah yaitu antara 32,64-34,11 kw/ha (Rukmana, 1994 dalam Rosmarkam, 2002).

Produksi terung di Nusa Tenggara Timur (NTT) tahun 2014 sebesar 2,586 ton, ha $^{-1}$ namun pada tahun 2015 turun menjadi 1,396 ton, ha ${ }^{-1}$. Hal ini diduga dikarenakan teknik budidaya yang kurang tepat dan daya dukung lahan yang rendah. Berdasarkan hal tersebut maka perlu dilakukan usaha peningkatan kualitas dan kuantitas produksi terung dengan penggunaan media tanam yang tepat.
Menentukan media tanam yang tepat yang akan digunakan dalam budidaya tanaman sangat sulit karena untuk menentukan media tanam yang baik harus memperhatikan iklim, cuaca, konsistensi tanah dan air yang berhubungan dengan cepat lambatnya pertumbuhan tanaman tersebut (Endriyani, 2010).

Media tanam sangat berperan dalam mendukung pertumbuhan dan perkembangan tanaman. Media yang baik dan tepat akan membantu pertumbuhan dan perkembangan tanaman secara baik. Pertumbuhan suatu tanaman juga sangat dipengaruhi oleh ketersediaan air dan unsur hara. Media tanam berfungsi sebagai tempat tumbuh dan berkembangnya akar serta menahan unsur hara dan air untuk pertumbuhan dan perkembangan tanaman (Sitawati, 1998). Jenis dan sifat media tanam akan mempengaruhi ketersediaan unsur hara dan air di daerah sekitar perakaran tanaman. Macam media akan berpengaruh terhadap pertumbuhan dan hasil tanaman. Perbedaan ini berhubungan dengan daya mengikat air dan unsur hara bagi tanaman serta porositas, kelembaban dan aerasi dalam media tanam (Foth, 1998). Pilihan jenis media tanam ditentukan oleh jenis tanaman yang akan ditanam. Media 
yang dipilih harus dapat memberikan pengaruh positif untuk proses budidaya. Banyak alternatif media selain tanah yang digunakan sebagai media tanam, seperti arang sekam, sabut kelapa dan kotoran sapi. Media tanam untuk pot dipilih dari bahan yang mudah didapat, mempunyai daya pegang air yang kuat, ringan dan murah. Hal ini agar budidaya tanaman pot mudah dilakukan dan juga tidak terlalu boros menggunakan air, serta apabila diberikan hara dalam bentuk larutan maka hara tersebut mampu bertahan dan digunakan secara optimal oleh tanaman pada media (Munir, 1996).

\section{METODE PENELITIAN}

Bahan yang digunakan dalam penelitian ini adalah tanah alfisol, arang sekam, pupuk kandang kotoran sapi, arang serbuk sabut kelapa, dan benih terung teho (varietas HYBRIDA F1). Alat yang digunakan dalam penelitian ini adalah polybag, linggis, sekop, mistar, timbangan, kamera, seng, dan alat tulis menulis.

Penelitian ini dirancang dalam rancangan lingkungan berupa Rancangan Acak Lengkap (RAL), dengan 8 perlakuan dan 3 ulangan sehingga secara keseluruhan terdapat 24 unit percobaan. Perlakuan yang dicobakan dibuat berdasarkan perbandingan volume. Perlakuan yang diberikan adalah sebagai berikut:

P1: Tanah (100\%),

P2: Tanah dan arang sekam padi (1:1)

P3: Tanah dan pupuk kandang kotoran sapi

P4: Tanah dan arang serbuk sabut kelapa $(1: 1)$

P5: Tanah dengan arang sekam padi dan pupuk kandang kotoran sapi $(1: 1: 1)$

P6: Tanah dengan arang sekam padi dan arang serbuk sabut kelapa $(1: 1: 1)$

P7: Tanah dengan pupuk kandang kotoran sapi dan Arang serbuk sabut kelapa (1:1:1)

P8: Tanah dengan arang sekam padi dan pupuk kandang kotoran sapi serta arang serbuksabut kelapa $(1: 1: 1: 1)$.

Model matematika untuk percobaan faktor tunggal dengan rancangan lingkungan berupa Rancangan Acak Lengkap (RAL) menurut Sastrosupadi (2000) sebagai berikut:

$$
Y_{i j}=\mu+T_{i}+\sum_{i j}
$$

Keterangan:

$\mathrm{Y}_{\mathrm{ij}}=\quad$ Nilai pengamatan pada perlakuan ke

- i ulangan ke - j

$\mu=\quad$ Nilai Tengan Umum

$\mathrm{T}_{\mathrm{i}}=\quad$ Pengaruh perlakuan ke $-\mathrm{i}$ 
Hali, A., \& Telan, A. (2018). Pengaruh Beberapa Kombinasi Media Tanam Organik Arang Sekam, Pupuk Kandang Kotoran Sapi, Arang Serbuk Sabut Kelapa Dan Tanah Terhadap Pertumbuhan Dan Hasil

Tanaman Terung (Solanum Melongena L.). JURNAL INFO KESEHATAN, 16(1), 83-95. https://doi.org/10.31965/infokes.Vol16.Iss1.174

$\sum_{\mathrm{ij}}=$ Pengaruh galat percobaan dari perlakuan ke - i dan ulangan ke

$-\mathrm{j}$

$\mathrm{i}=\quad$ Jumlah perlakuan

$\mathrm{j}=\quad$ Jumlah ulangan

Data yang diperoleh dari hasil pengamatan pertumbuhan dan hasil tanaman di analisis dengan sidik ragam untuk melihat pengaruh perlakuan yang dicobakan, dan dilanjutkan dengan uji jarak Duncan (DMRT) pada taraf 5\%.

Persiapan penelitian didahului dengan persiapan benih terung di semai terlebih dahulu sebelum penanaman. Proses penyemaian dilakukan secara steril pada media tanam. Biji dikecambahkan pada media yang telah disediakan selama 26 hari (3 minggu 5 hari). Selanjutnya bibit terung yang memiliki daun sempurna tersebut dipindahkan ke polybag setelah muncul 2-3 helai daun. Kemudian bibit ditanam pada media sesungguhnya yakni pada polybag yang telah diisi dengan media tanam. Kegiatan pemeliharaan meliputi penyiraman yang dilakukan 2 kali sehari yakni pada pagi dan sore hari dengan cara menyiram air kedalam polybag dan tidak terlalu berlebihan hingga kapasitas lapang. Penyulaman dilakukan pada tanaman terserang hama dan penyakit, mati atau tumbuh abnormal sebelum tanaman berumur dua minggu setelah tanam (MST). Penyiangan dilakukan setiap minggu setelah tanam dan pembubunan tanah dilakukan bersamaan dengan penyiangan yang dikerjakan secara hati-hati dan diusahakan agar jangan sampai mengganggu pertumbuhan akar tanaman. Pengendalian hama dan penyakit dilakukan secara mekanis dengan melihat intensitas serangan yang ada dilapangan. Pemanenan terung dilakukan pada saat buah terung memasuki stasiun matang dengan ciri-ciri sebagian besar permukaan buah berwarna hitam mengkilap dan pas waktunya untuk dipanen atau presentasenya 20\% kecuali pada panen terahir semua buah yang kecil atau yang besar juga ikut dipanen. Panen dilakukan sebanyak 3 kali dengan interval panen 2 hari sekali.

\section{HASIL DAN PEMBAHASAN}

\section{A. Tinggi Tanaman Terung}

Hasil pengamatan tinggi tanaman terung dari 2 MST, 4 MST, 6MST, 8 MST dan 10MST. Hasil analisis keragaman menunjukkan bahwa perlakuan kombinasi media tanam organik arang sekam, kotoran sapi, sabut kelapa dan tanah berpengaruh 
tidak nyata terhadap pertumbuhan tanaman terung pada periode umur 2 MST namun selanjutnya memperlihatkan pengaruh nyata pada periode umur 4MST, 6MST, 8MST dan10 MST.

Berdasarkan hasil uji BNJ 5\% pada terlihat bahwa pertumbuhan tanaman terung pada umur 2MST media tanam belum memberikan pengaruh terhadap pertumbuhan tanaman dikarenakan tanaman masih menyesuaikan diri dengan lingkungan yang barudan pada umur tersebut tanaman belum bisa secara sempurna mengambil nutrisi yang disediakan oleh media tanam tetapi masih mengandalkan persediaan makanan yang ada. Pada umur 4MST, 6MST, 8MST dan 10MST tinggi tanaman terung tertinggi ditemukan pada perlakuan kombinasi media tanah, arang sekam padi, kotoran sapi dan arang sabut kelapa $(1: 1: 1: 1)$ P8 namun tidak berbeda nyata dengan perlakuan media tanah dan kotoran sapi (1:1)P3 dan media tanah, pupuk kandang sapi dan arang sabut kelapa (1:1:1) P7 pada umur 6 MST , 8 MST dan 10 MST

Tabel 4.1 Pengaruh Komposisi Media Tanam Organik Terhadap Rerata Tinggi Tanaman Terung Pad Umur 2 MST 4MST, 6MST, 8 MST dan 10 MST

\begin{tabular}{|c|c|c|c|c|c|}
\hline \multirow[t]{2}{*}{$\begin{array}{l}\text { Perlakuan Komosisi Media } \\
\text { Tanam }\end{array}$} & \multicolumn{5}{|c|}{$\begin{array}{l}\text { Tinggi Tanaman Terung } \\
(\mathrm{cm})\end{array}$} \\
\hline & 2MST & $4 \mathrm{MST}$ & $6 \mathrm{MST}$ & $8 \mathrm{MST}$ & $10 \mathrm{MST}$ \\
\hline P1 (Tanah 100\%) & 803 & $12,83 \mathrm{r}$ & $24,97 \mathrm{ab}$ & $42,37 \mathrm{ab}$ & $46,90 \mathrm{ab}$ \\
\hline $\begin{array}{l}\text { P2 (Tanah : Arang SekamPadi } \\
(1: 1))\end{array}$ & $9,93 \mathrm{a}$ & $12,53 \mathrm{ab}$ & $18,03 \mathrm{a}$ & $30,20 a$ & $46,60 \mathrm{ab}$ \\
\hline $\begin{array}{l}\text { P3 (Tanah : Pupuk Kandang } \\
\text { Sapi }(1: 1))\end{array}$ & $11,03 \mathrm{a}$ & $15,13 \mathrm{ab}$ & 37 & $66,57 \mathrm{c}$ & $77,36 \mathrm{c}$ \\
\hline $\begin{array}{l}\text { P4 (Tanah: Arang Sabut } \\
\text { Kelapa }(1: 1))\end{array}$ &, $37 \mathrm{a}$ & $11,43 \mathrm{a}$ & $18,60 \mathrm{a}$ & $25,80 \mathrm{a}$ & $34,53 \mathrm{a}$ \\
\hline $\begin{array}{l}\text { P5 (Tanah : Arang sekam padi } \\
\text { : Pupuk Kandang sapi }(1: 1: 1))\end{array}$ & $9,13 \mathrm{a}$ & $11,10 \mathrm{a}$ & 22, & $62,83 \mathrm{bc}$ & $84,83 c$ \\
\hline $\begin{array}{l}\text { P6 (Tanah: Arang Sekam Padi } \\
\text { : Arang Sabut Kelapa }(1: 1: 1))\end{array}$ & $11,00 \mathrm{a}$ & $12,47 \mathrm{ab}$ & $7 \mathrm{a}$ & $22,10 \mathrm{a}$ & $32,73 a$ \\
\hline $\begin{array}{l}\text { P7 (Tanah:Pupuk Kandang } \\
\text { sapi :Arang Sabut Kelapa } \\
(1: 1: 1))\end{array}$ & $11,90 a$ & $16,97 \mathrm{ab}$ & $40,47 \mathrm{c}$ & $66,10 \mathrm{c}$ & $73,43 \mathrm{bc}$ \\
\hline $\begin{array}{l}\text { P8 (Tanah : Arang Sekam Padi } \\
: \quad \text { Pupuk Kandang sapi : } \\
\text { ArangSabut Kelapa }(1: 1: 1: 1))\end{array}$ & $11,57 \mathrm{a}$ & $18,56 b$ & $43,17 \mathrm{c}$ & $70,70 \mathrm{c}$ & $77,03 \mathrm{c}$ \\
\hline
\end{tabular}

Keterangan : Angaka-angka dalam kolom yang diikuti oleh huruf berbeda, bermakna berbeda pada taraf uji Beda Nyata Jujur (BNJ) 5\%.

Arang sekam padi, arang sabut kelapa dan pupuk kandang kotoran sapi yang merupakan bahan organik, apabila dikombinasikan dengan tanah akan menciptakan aerasi dan drainase yang baik. Hal tersebut akan memungkinkan unsur 
Hali, A., \& Telan, A. (2018). Pengaruh Beberapa Kombinasi Media Tanam Organik Arang Sekam, Pupuk Kandang Kotoran Sapi, Arang Serbuk Sabut Kelapa Dan Tanah Terhadap Pertumbuhan Dan Hasil

Tanaman Terung (Solanum Melongena L.). JURNAL INFO KESEHATAN, 16(1), 83-95. https://doi.org/10.31965/infokes.Vol16.Iss1.174

| 89

hara yang terdapat dalam media tanam tersebut dapat dimanfaatkan dengan baik oleh tanaman. Pupuk kandang kotoran sapi yang mengandung unsur hara makro yang cukup tinggi terutama nitrogen $(\mathrm{N})$ yang sangat berperan dalam pertumbuhan vegetatif tanaman termasuk tinggi tanaman. Nitrogen diperlukan oleh tanaman untuk merangsang pertumbuhan vegetatif tanaman seperti perpanjangan akar, batang dan daun yang mempengaruhi tinggi tanaman.

Pada umur 4MST, 6MST, 8MST dan 10MST pertumbuhan tanaman terendah ditemukan pada perlakuantanah, arang sekam padi, arang sabut kelapa $(1: 1: 1)$ P6 dan pertumbuhan tanaman terendah pada umur tersebut tidak berbeda nyata dengan perlakuan P1, P2 dan P4 dan sangat berbeda nyata dengan perlakuan P3, P5, P7 dan P8.Hal ini dikarenakan media tanam arang sekam padi, arang sabut kelapa dan tanah mengandung sedikit unsur hara sehingga pertumbuhan tanaman terhambat yang dapat dilihat pada tinggi tanaman yang lebih rendah. Media tanam meskipun telah dikombinasikan dengan tanah, arang sekam padi maupun arang sabut kelapa belum dapat menunjukkan pertumbuhan dalam hal ini tinggi tanaman yang signifikan. Diduga unsur hara yang terkandung dalam media tanam tersebut belum mampu memenuhi kebutuhan tanaman terung. Porositas dari media tanam arang sekam dan arang sabut kelapa yang cukup besar menyebabkan media tanam tersebut cepat meloloskan air sehingga tanaman cenderung mengalami kekurangan air untuk kelangsungan pertumbuhannya.

\section{B. Jumlah Daun Terung}

Hasil analisis keragaman menunjukkan bahwa perlakuan kombinasi media tanam organik arang sekam padi, pupuk kandang sapi, arang sabut kelapa dan tanah, berpengaruh tidak nyata pada umur 2 MST dan sangat nyata terhadap jumlah daun pada umur 4 MST, 6 MST, 8 MST, dan 10 MST tanaman terung. 
Tabel 4.2 Pengaruh Komposisi Media Tanam Organik Terhadap Jumlah Daun Tanaman Terung Dari 2 MST, 4 MST, 6MST, 8 MST dan 10 MST

\begin{tabular}{|c|c|c|c|c|c|}
\hline \multirow{2}{*}{$\begin{array}{l}\text { Perlakuan Komosisi } \\
\text { Media Tanam }\end{array}$} & \multicolumn{5}{|c|}{ Rerata Pertambahan Jumlah Daun } \\
\hline & 2MST & 4MST & $6 \mathrm{MST}$ & $8 \mathrm{MST}$ & 10MST \\
\hline P1 Tanah $100 \%$ & $4,33 \mathrm{a}$ & $6,67 \mathrm{abcd}$ & $9.00 \mathrm{abc}$ & $14.00 \mathrm{ab}$ & $15.33 \mathrm{ab}$ \\
\hline $\begin{array}{l}\text { P2 Tanah : Arang } \\
\text { SekamPadi }(1: 1)\end{array}$ & $5,00 \mathrm{a}$ & $5,00 \mathrm{ab}$ & $6.67 \mathrm{bcd}$ & $8.67 \mathrm{a}$ & $11.33 \mathrm{a}$ \\
\hline $\begin{array}{l}\text { P3 Tanah : Pupuk } \\
\text { Kandang Sapi }(1: 1)\end{array}$ & $5,00 \mathrm{a}$ & $7,33 \mathrm{bcd}$ & $11.67 \mathrm{bcd}$ & $27.67 \mathrm{bc}$ & $48.33 \mathrm{bc}$ \\
\hline $\begin{array}{l}\text { P4 Tanah: Arang Sabut } \\
\text { Kelapa }(1: 1)\end{array}$ & $4,67 \mathrm{a}$ & $4,67 \mathrm{a}$ & $6.00 \mathrm{a}$ & $7.00 \mathrm{a}$ & $8.33 \mathrm{a}$ \\
\hline $\begin{array}{l}\text { P5 Tanah : Arang } \\
\text { sekam padi : Pupuk } \\
\text { Kandang sapi }(1: 1: 1)\end{array}$ & $4,67 a$ & $5,67 \mathrm{abc}$ & $9.00 \mathrm{abc}$ & $22.67 \mathrm{abc}$ & $36.67 \mathrm{abc}$ \\
\hline $\begin{array}{l}\text { P6 Tanah: Arang Sekam } \\
\text { Padi : Arang Sabut } \\
\text { Kelapa }(1: 1: 1)\end{array}$ & $4,67 \mathrm{a}$ & $4,67 \mathrm{a}$ & $5.33 \mathrm{a}$ & $7.00 \mathrm{a}$ & $8.33 \mathrm{a}$ \\
\hline $\begin{array}{l}\text { P7 Tanah: Pupuk } \\
\text { Kandang Sapi :Arang } \\
\text { Sabut Kelapa }(1: 1: 1)\end{array}$ & $4,33 \mathrm{a}$ & $8,00 \mathrm{~cd}$ & $12.00 \mathrm{~cd}$ & $34.33 \mathrm{c}$ & $57.67 \mathrm{c}$ \\
\hline $\begin{array}{l}\text { P8 Tanah : Arang } \\
\text { Sekam Padi : Pupuk } \\
\text { Kandang Sapi : } \\
\text { ArangSabut Kelapa } \\
(1: 1: 1: 1)\end{array}$ & $5,00 \mathrm{a}$ & $8,67 \mathrm{~d}$ & $15.33 \mathrm{~d}$ & $40.33 \mathrm{c}$ & $65.67 \mathrm{c}$ \\
\hline
\end{tabular}

Berdasarkan data hasil uji BNJ 5\% pada Tabel 4.2 diatas bahwa jumlah daun pada umur 2MST berkisar 4,33 - 5,00. Pada umur 4MST, 6MST, 8MST dan 10MST tertinggi diperoleh pada perlakuan tanah, arang sekam padi, pupuk kandang sapi, arang sabut kelapa $(1: 1: 1: 1)$ P8 dan jumlah daun tertinggi pada umur tersebut tidak berbeda nyata dengan perlakuan P3, P5 dan P7. Hal tersebut disebabkan oleh peranan pupuk kandang sapi sebagai bahan organik yang dapat menyediakan ion-ion hara tersedia bagi tanaman. Adanya bahan organikjuga dapat menghindari terjadinya proses pelindian ion hara oleh aliran massa air. Bahan organik juga dapat meningkatkan kapasitas memegang air dan kapasitas tukar kation (KTK) tanah.
Data pengamatan jumlah daun pada umur 4MST, 6MST, 8MST dan 10MST terendah diperoleh pada perlakuan tanah, arang sabut kelapa (1:1) P4 dan pelakuan tanah, arang sekam padi, arang sabut kelapa (1:1:1) P6 dan berbeda tidak nyata dengan perlakuan P1 dan P2. Hal ini disebabkan karena pada pemberian media tanam terutama pada media tanam arang sekam padi dan arang sabut kelapa sangat sulit untuk terdekomposisi. Ini dikarenakan pada media tanam arang sekam padi dan arang sabut kelapa memiliki kandungan lignin, dimana jika pada suatu media mengandung unsur lignin yang tinggi, maka keadaan seperti ini akan mengakibatkan kurangnya laju pembusukan pada media tanam yang 
Hali, A., \& Telan, A. (2018). Pengaruh Beberapa Kombinasi Media Tanam Organik Arang Sekam, Pupuk Kandang Kotoran Sapi, Arang Serbuk Sabut Kelapa Dan Tanah Terhadap Pertumbuhan Dan Hasil

Tanaman Terung (Solanum Melongena L.). JURNAL INFO KESEHATAN, 16(1), 83-95. https://doi.org/10.31965/infokes.Vol16.Iss1.174

| 91

mengakibatkan rendahnya persediaan unsur hara dan mengakibatkan pertumbuhan tanaman menjadi kurang baik. Hal ini dapat kita lihat pada perlakuan P4 dan P6 yang mengalami lambatnya pertumbuhan daun. Seperti hasil penelitian yang dikemukakan oleh Kasumboga (1997), arang sekam memiliki banyak kandungan lignin, selulosa dan hemiselulosa. Lignin merupakan senyawa organiksebagi sumber penyedia C organik, dan lignin juga memiliki sifat yang sulit untuk terdekomposisi sehingga belum bisa menyediakan kondisi lingkungan tumbuh yang berpengaruh pada pertambahan jumlah daun pada tanaman terung.

Tabel 4.3 Pengaruh Komposisi Media Tanam Organik Terhadap Jumlah BuahTerung

\begin{tabular}{l|c|}
\hline \multicolumn{1}{|c|}{ Perlakuan Komposisi Media Tanam } & Jumlah Buah \\
\hline P1 Tanah $100 \%$ & $1,3 \mathrm{abc}$ \\
\hline P2 Tanah : Arang SekamPadi $(1: 1)$ & $0,00 \mathrm{a}$ \\
\hline P3 Tanah : Pupuk Kandang Sapi $(1: 1)$ & $4,33 \mathrm{~d}$ \\
\hline P4 Tanah: Arang Sabut Kelapa $(1: 1)$ & $0,00 \mathrm{a}$ \\
\hline $\begin{array}{l}\text { P5 Tanah : Arang sekam padi : Pupuk Kandang } \\
\text { sapi (1:1:1) }\end{array}$ & $3,33 \mathrm{~cd}$ \\
\hline $\begin{array}{l}\text { P6 Tanah: Arang Sekam Padi : Arang Sabut Kelapa } \\
\text { (1:1:1) }\end{array}$ & $0,33 \mathrm{ab}$ \\
\hline $\begin{array}{l}\text { P7 Tanah:Pupuk Kandang sapi :Arang Sabut Kelapa } \\
\text { (1:1:1) }\end{array}$ & $3,00 \mathrm{bcd}$ \\
\hline $\begin{array}{l}\text { P8 Tanah : Arang Sekam Padi : Pupuk Kandang sapi } \\
: \text { ArangSabut Kelap (1:1:1:1) }\end{array}$ & $3,33 \mathrm{~cd}$ \\
\hline \multicolumn{1}{|c|}{ Keterangangana-angka dalam kolom yang diikuti oleh huruf berbeda, } \\
\hline
\end{tabular}

Kombinasi media tanam organik terhadap jumlah buah terung. Jumlah buah arang sekam padi, arang sabut kelapa, pupuk kandang kotoran sapi dan tanah memberikan pengaruh yang sangat nyata terdekomposisi sehingga belum bisa menyediakan kondisi lingkungan tumbuh yang berpengaruh pada pertambahan jumlah daun pada tanaman terung.

\section{Jumlah Buah}

Hasil pengamatan terhadap jumlah buah terung satu minggu sebelum panen yang disajikan pada lampiran 2, data 11 a. Hasil analisis keragaman menunjukkan bahwa terdapat pengaruh yang sangat nyata terhadap perlakuan kombinasi media tanam organik tanah, arang sekam padi, arang sabut kelapa dan pupuk kandang kotoran sapi terhadap jumlah buah terung. 
P7 dan P8. Hal ini disebabkan oleh unsur hara $\mathrm{N}, \mathrm{P}, \mathrm{K}$ organik yang terkandung dalam pupuk kandang kotoran sapi dengan dosis yang lebih besar mengandung kuantitas yang besar pula sehingga ketersediaan dan kontribusinya bagi tanaman akan lebih tersedia dan besar.

Data jumlah buah terung terendah terdapat pada perlakuan tanah, arang sekam padi (1:1) P2 dan perlakuan tanah, arang sabut kelapa (1:1) P4 dimana pada kedua perlakuan ini tanaman terung tidak menghasilkan buah, tetapi tidak berbeda nyata dengan perlakuan P1 dan P6. Pad perlakuan P2 dan P4 Tanaman terung sempat menghasilkan beberapa bunga, tetapi bunga yang di hasilkan tanaman terung gugur sehingga tidak menghasilkan buah.

Unsur hara N, P, K organik secara langsung sangat berperan mendukung pertumbuhan vegetatif dan generatif tanaman khususnya dalam pembungaan tanaman dan mencegah gugurnya bunga. Hal ini didukung oleh pernyataan Prihmantoro,1996 dalam Syarifah, dkk, 2016, yang menyatakan bahwa pada fase vegetatif tanaman membutuhkan kalium untuk proses pembungaan dan membutuhkan fosfor untuk pembentukan buah dengan memanfaatkan faktor tumbuh, maka akan mencegah gugurnya bunga sehingga jumlah buah yang dihasilkan akan meningkat.

\section{Bobot Buah}

Hasil analisis keragaman menunjukkan bahwa terdapat pengaruh yang sangat nyata pada perlakuan kombinasi media tanam organik arang sekam padi, pupuk kandang kotoran sapi, arang sabut kelapa dan tanah terhadap hasil berat buah terung.

Tabel 4.4.Bobot Buah Terung Akibat Perlakuan KombinasiMedia Tanam

\begin{tabular}{|c|c|}
\hline Perlakuan komosisi media tanam & Bobot Buah \\
\hline P1 Tanah $100 \%$ & $69,86 a$ \\
\hline P2 Tanah : Arang SekamPadi (1: 1) & $0,00 a$ \\
\hline P3 Tanah : Pupuk Kandang Sapi (1 : 1) & $417,200 b$ \\
\hline P4 Tanah: Arang Sabut Kelapa (1 : 1) & $0,00 \mathrm{a}$ \\
\hline $\begin{array}{l}\text { P5 Tanah : Arang Sekam Padi : Pupuk } \\
\text { Kandang Sapi }(1: 1: 1)\end{array}$ & $422,53 \mathrm{~b}$ \\
\hline $\begin{array}{l}\text { P6 Tanah: Arang Sekam Padi : Arang Sabut } \\
\text { Kelapa }(1: 1: 1)\end{array}$ & $13,66 \mathrm{a}$ \\
\hline $\begin{array}{l}\text { P7 Tanah:Pupuk Kandang sapi :Arang Sabut } \\
\text { Kelapa }(1: 1: 1)\end{array}$ & $397,60 \mathrm{~b}$ \\
\hline $\begin{array}{l}\text { P8 Tanah : Arang Sekam Padi : Pupuk } \\
\text { Kandang Sapi : ArangSabut Kelapa }(1: 1: 1: 1)\end{array}$ & $382,03 \mathrm{~b}$ \\
\hline
\end{tabular}


Hali, A., \& Telan, A. (2018). Pengaruh Beberapa Kombinasi Media Tanam Organik Arang Sekam, Pupuk Kandang Kotoran Sapi, Arang Serbuk Sabut Kelapa Dan Tanah Terhadap Pertumbuhan Dan Hasil Tanaman Terung (Solanum Melongena L.). JURNAL INFO KESEHATAN, 16(1), 83-95. https://doi.org/10.31965/infokes.Vol16.Iss1.174

Hasil tanaman terung saat panen ditentukan oleh berbagai kombinasi media tanam organik. Bobot buah tanaman terung yang paling tinggi pada saat panen ditemukan pada perlakuan media tanam organik tanah, arang sekam padi dan pupuk kandang sapi 1:1:1 (P5) tetapi berbeda tidak nyata dengan tiga perlakuan lainnya yaitu perlakuan P3, P7 dan P8.

Bobotbuah terung nyata tertinggi diduga karena pada perlakuan kombinasi ini memberikan pertumbuhan yang baik, yang di tandai dengan pertambahan tinggi tanaman dan jumlah daun yang lebih banyak, selain itu adanya sumbangan unsur hara yang cukup dari perlakuan kombinasi media tanam yang salah satu bahan campuran organiknya adalah pupuk kandang kotoran sapi, yang menyediakan unsur hara makro dan mikro dan kondisi fisik serta biologi media tanam yang optimal. Kondisi demikian mengakibatkan terjadinya peningkatan laju fotosintesis dan fotosintat yang dihasilkan menjadi meningkat. Pertumbuhan tanaman sangat memerlukan fotosintat, dengan meningkatnya fotosintat (karbohidrat) yang terbentuk akan berpengaruh terhadap bobotbuah terung.
Bobot buah terung terendah pada saat panen ditemukan pada perlakuan P1 dan P6 tetapi berbeda tidak nyata dengan perlakuan P2 dan P4. Hal ini disebabkan arang sekam padi yang ditambahkan sulit terdekomposisi sehingga lambat tersedia bagi tanaman dan pertumbuhan tanaman terhambat. Selain itu, kondisi media tanam lebih remah sehingga tanaman tidak dapat berdiri kokoh disebabkan oleh perakaran yang tidak kuat dengan demikian mempengaruhi pembentukan buah sehingga besar kecilnya buah akan mempengaruhi bobotbuah. Mechram (2006) dalam Atmojo (2003), menambahkan bahwa arang sekam memiliki pori - pori makro yang besar, maka waktu bagi keadaan air tersedia menjadi pendek sehingga memperkecil jumlah air yang dapat diserap oleh akar. Kecilnya penyerapan air mempengaruhi hasil fotosintesis yang selanjutnya berpengaruh terhadap pertumbuhan dan hasil tanaman.

\section{KESIMPULAN}

Berdasarkan hasil analisis data dan uraian pembahasan yang telah dikemukakan, maka dapat disimpulkan bahwa kontribusi pupuk kandang sapipada media tanam sangat berpengaruh nyata 
terhadap pertumbuhan dan hasil tanaman terung yaitupada variabel pengamatan tinggi tanaman, jumlah daun, jumlah buah dan bobot buah. Untuk perlakuan kombinasi media tanam organik tanah, arang sekam padi, pupuk kandang sapi, dan arang sabut kelapa (1:1:1:1) menghasilkan tinggi tanaman, jumlah daun, jumlah buah dan bobot buah terung terbaik, namun tidak berbeda signifikan dengan perlakuan P3, P5, dan P7.

\section{REFERENCES}

Afandie Rosmarkam dan Nasih Widya Yuwono. (2002). Ilmu Kesuburan Tanah dan Tanaman. Kanisius. Yogyakarta

Anonim. (2010). Macam-macam Media Tanam.http://kangtoo.wordpress.c om/. Diakses pada tanggal 2 November 2016.

Atmojo, S. W, (2003). Peranan Bahan Organik Terhadap Kesehatan Tanah Dan Upaya Pengelolaannya. Pidato pengukuhan Guru Besar Ilmu Kesehatan Tanah Universitas Sebelas Maret. Sebelas Maret Universiti Press. Surakarta

Endriani.(2010). Sifat Fisika dan Kadar Air

Tanah Ultisol Akibat Penerapan Sistem Olah Tanah Konservasi. Jurnal Hidrolitan. Vol. 1. No. 1. Masyarakat
Konservasi Tanah dan Air (MKTI)

Cabang Jambi.Jambi

Foth, H. D. (1998). Dasar-Dasar Ilmu Tanah. Gajah Mada University Press.Yokjakarta.

Gusmini, N. Hakim dan F. E. Husin. (2003). Pengaruh Pemberian Tithonia Diversifolia, L sebagai Sumber N Dan K dalam Mensubsidi Pupuk Buatan. Jurnal Teknologi. Bandung Hakim. (2002). Dasar-Dasar Ilmu Tanah. Universitas Lampung Press. Bandar Lampung.

Hardjowigeno, S. (2013). Klasifikasi Tanah Alfisol. Departemen Ilmu-Ilmu Tanah. Fapeta ITB. Bogor.

Hanolo, W. (1997). Tanggapan Tanaman Selada dan Sawi Terhadap Dosis dan Cara Pemberian Pupuk Hijau. Jurnal AgotroPika 1(r):25-29

Hatatik. W. (2007). Pemanfaatan Gulma Tithonia Sebagai Sumber Bahan Organik. Jurnal Penelitian, vol. 29. Leba, Kahi.(2004). Frekuensi Pemberian

$$
\begin{aligned}
& \text { Air Terhadap Tanaman Pada } \\
& \text { Tanah Vertisol Dan Tanah } \\
& \text { Mediteran.Undana, Kupang. } \\
& \text { p:1 }
\end{aligned}
$$

Kasumbogo.U, (1997). Peranan Pertanian Organik Dalam Pembangunan Berwawasan Lingkungan, Yayasan Bumi Lestari. 
Hali, A., \& Telan, A. (2018). Pengaruh Beberapa Kombinasi Media Tanam Organik Arang Sekam, Pupuk Kandang Kotoran Sapi, Arang Serbuk Sabut Kelapa Dan Tanah Terhadap Pertumbuhan Dan Hasil

Tanaman Terung (Solanum Melongena L.). JURNAL INFO KESEHATAN, 16(1), 83-95.

https://doi.org/10.31965/infokes.Vol16.Iss1.174

Munir. M. (1996). Tanah-Tanah Utama Di Indonesia, Karakteristik, Klasifikasi dan Pemanfaatannya. Penerbit Sitawati, A., Nugroho, C., dan A. Suryanto. Pustaka Jaya.

Oviyanti, F., Syarifah dan Nurul Hidayah. (2016). Pengaruh Pemberian Pupuk Organik Cair Daun Gamal (Gliricidia sepium (Jacq.) Kunth ex Walp. Terhadap Pertumbuhan Tanaman Sawi (Brassica juncea L.). Jurnal Biota Vol. 2 No. 1 edisi Januari 2016. Pp: $61-67$.

Sastrosupadi, A., (2000). Rancangan Percobaan Praktis Bidang
Pertanian. Penerbit Kanisus. Yogyakarta. (1998). Pengaruh Berbagai Media dan Hara terhadap Pertumbuhan Tanaman Lombok Besar (Capsicum annum) dalam Budidaya Sistem Pot. J. penelitian Ilmu Hayati. Vol. 10 No. Universitas Brawijaya, Malang.

Soerodjotanoso, (1993). Pengembangan Tanaman Lamtoro pada TanahTanah Kritis.

Sutedjo, M.M, (1992). Analisa Tanah, Air dan Jaringan Tanaman. PT Rineka Cipta Jakarta.

Ready to submit your research? Choose INFOKES and benefit from:

- fast, convenient online submission

- $\quad$ thorough peer review by experienced researchers in your field

- $\quad$ rapid publication on acceptance

- support for research data

- Open Access which fosters wider collaboration and increased citations

- maximum visibility for your research

At Health Polytechnic of Kupang, research is always in progress.

Learn more http://jurnal.poltekkekupang.ac.id/index.php/infokes 